Journal of Economics and Behavioral Studies

Vol. 3, No. 3, pp. 177-184, Sep 2011 (ISSN: 2220-6140)

\title{
The Relationship between Financial Repression and Financial Depth (Case study of Iran)
}

\author{
${ }^{1}$ Safdari Mehdi, ${ }^{2}$ Motiee Reza* \\ ${ }^{1}$ Department of Economics, Babol Branch, Islamic Azad University, Babol, Iran \\ *rm.search2011@gmail.com
}

\begin{abstract}
Financial repression introduced early decade 1970 by McKinnon (1988) and Shaw (1973) that represented limits created by governments on monetary and financial system and had a negative impact on financial markets but in some countries, financial repression has had a positive effect on the financial markets. Iran is among the countries that knows necessary suppression of the financing for the economy and of decade 1350 until now is applied many restrictions on the financial markets. In this article we use the econometric methodology "regression to the wide distribution breaks» (ARDL) are paid to analyze the relationship between financial depth and financial suppression of in India for the period 1976-2006 the result of this research has been the negative impact of financial suppression of on financial depth variable and if the government does not limit the financial markets, increased financial depth and can be useful for the economy. Due to error correction model (ECM) we confirm long-term relationship between variables and using the test (CUSUM, CUSUMQ), lack of structural failure in the model.
\end{abstract}

Keywords: Deep Financial, financial suppression, financial markets, Auto Regressive Distributed Lag (ARDL).

\section{Introduction}

Financial and monetary system can imagine as the engine driving the economy. This system tries to allocate scarce capital between costs that are in competition and it does method allocation resources to cost with maximum efficiency. There is no doubt that performance, stability and economic environment, maintaining a stable general price level, support production of and facilitate economic growth and development will realize if despite having a strong financial and monetary system in the community. Among the policies proposed in this system can be referred to policies of financial repression and financial depth. Financial repression is policies that are reason financial markets constraints by the government. When the economy financial markets variables including interest rates and deposit rates and be determined artificially out of the market the term is used to finance repression. Financial depth encompasses different definition that is different according to each market each country but such is the general definition that financial depth is called due to that amount of financial capital can move through various policies of visitors savings to investors. Iran is including countries that financial markets are limited to public and private banks that role of private banks is very pale compared state banks. Policies of financial repression can by limiting the market intensify to strengthening or weakening them. Financial depth that be represents the ability of financial markets to help investors should be determined factors affecting that until causes further increase it's be with the right policies and timely. Given that Iran is a developing country and is not benefit infrastructure integrity, should be clear that whether the policy of financial repression in the short term and long-term financial markets can be beneficial or not?

As regards financial markets in the Iran is controlled through the intervention order like determination interest rate bank deposits, determinacy facility and we find that backwardness of our financial markets to what extent is affected by financial repression or due to economic conditions, doing this repression by State has had what consequences for the economy. This method is method Regression with Auto Regressive Distributed Lag (ARDL). The cause of this method is being dynamic the model and power explain its high in relation interval effects on the dependent variable itself. To prove presence or absence of structural failure in the model cumulative total of the tests (CUSUM) and cumulative sum of squares (CUSUMQ) used and the error correction model (ECM) have discussed in connection with short-term model. This article has been arranged in the five main sections, in the first part of the background research, the second part will look in the situation financial repression in the Iran in the third section introduces the model and econometric method, fourth section estimates in the model and finally fifth Section we have conclusion. 


\section{Literature Review}

Issue that is raised and shows the economy more complex than itself is different conclusions about economic policy in the different countries. The theory of financial repression proves that has negative effects on economic growth and financial depth, but some countries in the world such as South Korea and Latin America, and some less developed countries to different results have reached in this matter. South Korea and Taiwan did not leave financial repression at their economies and gained positive results. In Latin America economic situation was worse than before the separation of financial repression, and China in a few cases did the liberating and became one of the world's economic powers. Shakeri and Khosravi (2004) in an article entitled "Theory test McKinnon- Shaw Iran's economy" is trying that placed in right direction economic development adopting appropriate interest rate policy; they finally empirically pay to test whether higher interest rates lead to higher rates investment in Iran. In the this study It was found that by increase real bank rate up to $2 \%$ in the Iranian economy increased investment rates, but in the higher rates of $2 \%$ reduced rate of investment and in other words occurs real bank rate of $2 \%$ in the bank a banking crisis that confirms the argument Estigeltez that high real rates increases the risk of the loans and the results they obtained rejects argument new structuralizes that, higher bank interest rates, is always cause reduction investment rate and confirms argument McKinnon- Shaw So that reduction real bank interest rates below zero percent is reason reduction investment rate in the Iran. Brownbridge and Gayi (1999) in their article barriers and limits financial sector reforms in the underdeveloped countries evaluate this policy in the countries, Madagascar, Malawi, Tanzania, Uganda, Zambia, Bangladesh, Laos and Nepal.

They are referring to the fact that banking system reform act through three mechanisms: Reduction the vulnerability of the financial system, reduction directs government intervention to pay loan to borrower that there is no guarantee to repay it's and restructuring banking system and applied proper regulatory oversight to banking system. The final result is researcher this is that in Countries reviewed is nothing desired results and arbitrary of financial liberalization and is set of failure this policy, interferences government and political pressures on banks and lack will enough to adherence to rules. Samadi (1999) in the their study titled "Financial repression and economic growth in the Iran: evaluation model McKinnon " is paid to mentioned pattern evaluation in the Iranian economy years 1341-1374 that results of the estimation, the desired equation, Support McKinnon-Shaw pattern and of hypothesis McKinnon Shaw being complementary. According findings this study can say if state officials to give daring copies of the financial repression through drop real interest rate ceilings, will increase level of investment and savings and this issue will lead this increase in revenue and ultimately economic growth.

Tornell, Westermann \& Martinez (2004) in an article titled the positive relationship between growth, liberalization and financial crises. To have concluded that in developing countries, following the liberalization of trade are financial liberalization which sometimes leads to financial fragility and occurrence crisis. On the other hand because in many countries has not been associated liberalization with judicial reform, many problems related to administrative requirements of rules 2 has emerged in developing countries. The researchers shows that in fact, asymmetry between the tradable sectors (T) 3 and non-tradable sectors (N) 4 economy is one of key points to understanding the relationship between liberalization and growth. Whereas many $\mathrm{T}$ section firms in a liberalized economy, with access to international capital markets can help overcome on the problem of financing, but $\mathrm{N}$-sector firms have limitations both financially and are dependent to domestic bank credit. They believe that financial liberalization, will accelerate to growth with accelerate financial deepening and thus investment firms which are faced with financial constraints, that often are concerned to section $\mathrm{N}$. On the other hand easier financial constraints, with accept the risk of non-payment 5 increases because that financial liberalization not only reduces the restrictions that would eliminate the risk, but eliminates the implied warranties systematic that protects the creditors against systemic crises. So it is clear that much of the incoming capital flows, are risk that used financial sector and the overall economy are facing with public tender and crisis.

Overview to status the financial Repression in Iran : In Iran looking at the status the financial repression, it is clear that in most cases government average, is running out of the financial repression, but Iran's financial markets and economic status in the country, tells unlike this issue. Here it is more clear this issue looking at the statistics obtained by the Bank and Statistical Center of Iran : 
- In an economy, privatization of financial markets, including banks, can be a sign of release of the financial repression. According to the chart below we see that contain a rising trend the share of non-state banks banking industry. It should be noted that a large the share of this increase is for established private banks, here to show the share of non-state banks from the banking industry, we have considered ratio bank deposits of non-governmental to total bank deposits as an indicator .

- The share of funds allocated to total funding of nongovernmental sector, is marker the financial liberalization and financial development, that it has been determined in the following chart .

Figure 1. Privatizations of banks

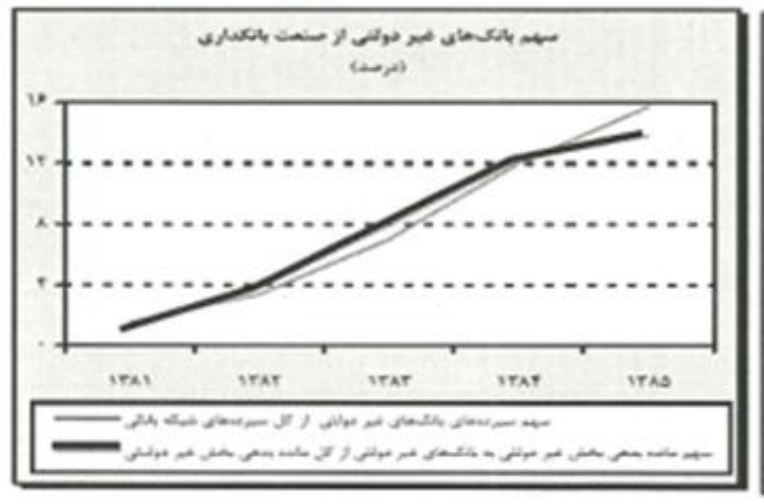

Figure 2. The share of credits allocated

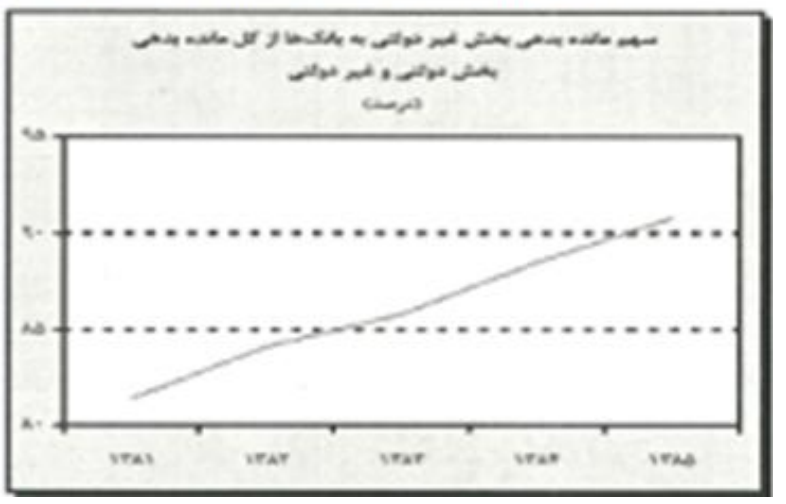

- Ratio assets of banks credit organizations to banking system assets is represents relative importance be deposited in financial institutions, that in Iran has had that growing trend in recent years.

- Ratio savings banks and credit institutions to total deposits of non-governmental sector, the resulting total additional resources and legitimate banks and credit institutions to Central Bank and also cash available in the fund banks on total deposits of non-governmental sector there are in the banks . Ratio mentioned is reflecting rate resource banks for create account and their ability to grant facilities .

Figure 3. Assets of banks and non-bank credit institutions

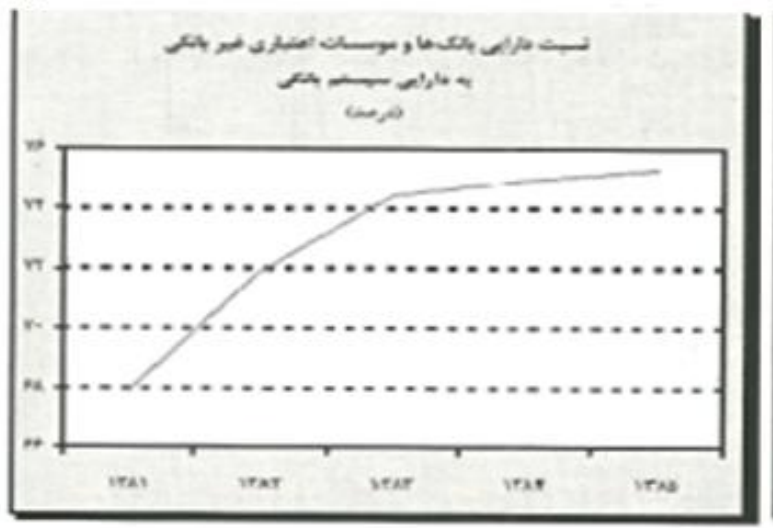

Figure 4. Savings Banks

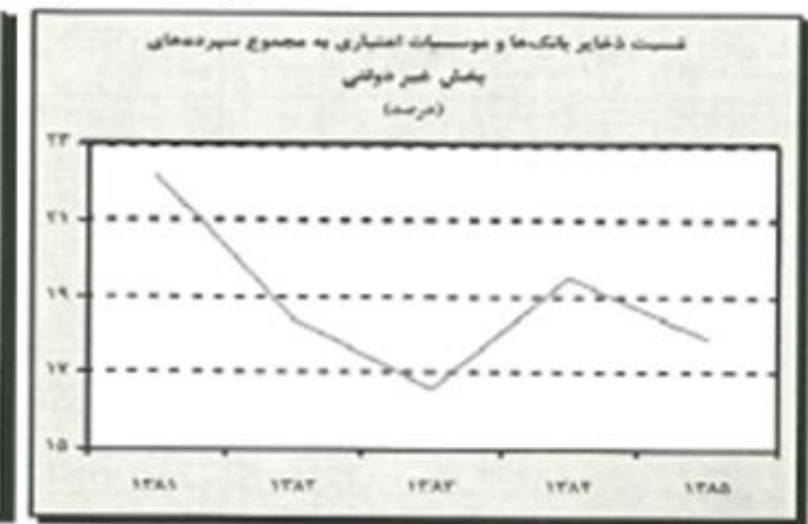

- Degree of focus banks is represents the share of deposits 3 first bank that have largest deposits in the banking network of total deposits that is indicates a lack of competition and inefficiencies in the banking network.

- Value added services and monetary and the financial institutions, is a combination of value added of banks and also value added of financial intermediation (stock exchange). 
Figure 5. Degrees of focus banks

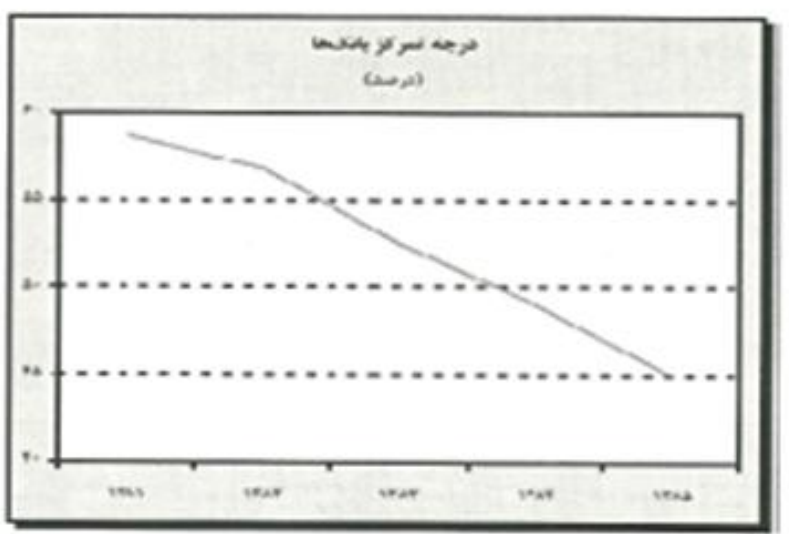

- Ratio current market value of shares to country's GDP is as the size stock market index .

- Ratio transaction value to GDP shows the ability to easily buy and sell securities and is another expression of the financial depth .

- Credit Control is of important channels for transmission effects monetary policy to the real economy .

- Credit Control is Indicator the financial repression, the process it has been determined for Iran in Fig 9.

Figure 7. Ratio current stock market value to GDP

Figure 8. Ratio transaction value to GDP
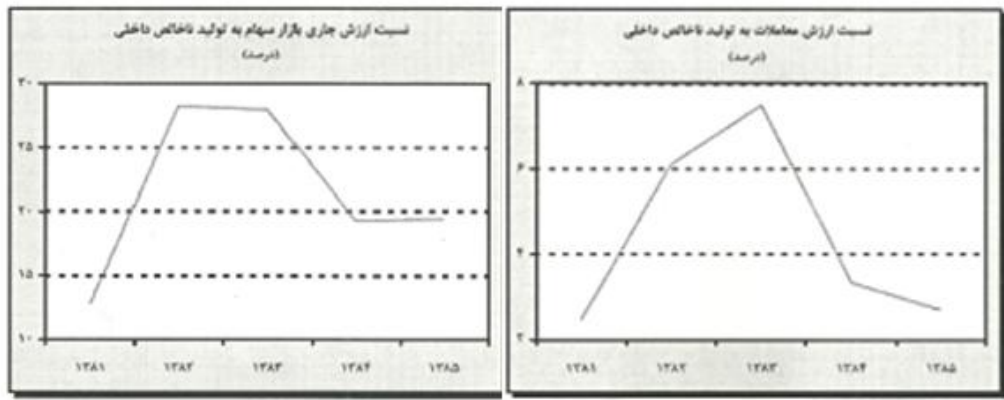

Figure 9. Ratio note Facility to total facility

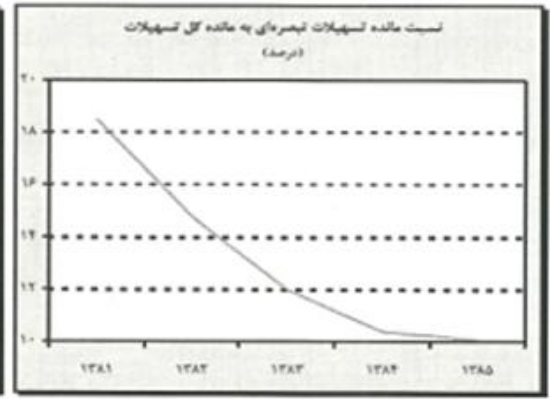

See figure 1 to 9 we know that in most areas, the Iranian government initiated financial liberalization and only the bond market, charts 2-7 and 2-8, has not been able to perform the required actions until will benefit from the relative stability this market. What there is now consensus on it, this is whatever financial systems are more developed and more savings, desired economy could experiences higher growth rates. Overall to increase the financial depth is needed to saving that as micro and small is among various sectors of society .

\section{Methodology}

In this section we pay to model stipulates and also different variables introduced that has been intended in recent years for financial depth and financial repression and we discuss about of each briefly .

Stipulates model:

In money market equilibrium we know that money supply equals money demand :

$M^{S}=M^{D}$

Overall demand for money, we can write as individual demand for money and we can rewrite It's as true :

$M^{S}=M^{D}=$ P.N. $m^{d}$ 
In this equation, $\mathrm{m}^{\mathrm{d}}$ is individual money demand that McKinnon and Shaw's theory has been function of the following variables :

$$
m^{d}=f\left(y_{p}, v, d-\pi^{e}\right)
$$

In equation demand for individual money has been per capita income and opportunity cost of money and, true interest rate. Fry 1995 in book "Money, Interest Banking in Economic Development" implies that demand for individual money is following figure that has used the McKinnon and Shaw's theory:

$m^{d}=c y_{p}^{a} e^{\beta d-\pi^{e}} v^{\gamma}$

That according to equation (2) is written as face:

$$
\frac{M^{D}}{P}=N c y_{p}^{\alpha} e^{\beta\left(d-\pi^{e}\right)} v^{\gamma}
$$

If we expand the per capita income then:

$$
\frac{M^{D}}{P}=N c \frac{y}{N} y_{p}^{\alpha-1} e^{\beta\left(d-\pi^{e}\right)} v^{\gamma}
$$

Finally be written as follows:

$$
\frac{\frac{M^{D}}{P}}{Y}=c y_{p}^{\alpha-1} e^{\beta\left(d-\pi^{e}\right)} v^{\gamma}
$$

For the linear model can take logarithms the sides the equation:

$\operatorname{LOG}\left(\frac{\frac{M^{D}}{P}}{P}\right)=\operatorname{LOG}\left(c y_{p}^{\alpha-1} e^{\beta\left(d-\pi^{e}\right)} v^{\gamma}\right)^{(8)}$

Dependent variable models in the economy, called financial depth has shown that it's as FD after opening the logarithm becomes equation as linear:

$$
\operatorname{LOG}(F D)=C_{0}+C_{1} L O G\left(y_{p}\right)+C_{2}\left(d-\pi^{e}\right)+C_{3} L O G(v)
$$

In equation (9), is the best variable replacement per capita the number of bank customers as opportunity cost of money, that goes up opportunity cost with increasing customer per capita bank, and people should spend more time for removal and saving their money in banks .

$d-\pi^{e}$ is the expression of real interest rates, we show the form of financial repression of $F R$, so that be determined with lower interest rates that has increased financial repression of these conditions the final equation for estimate becomes as follows:

$$
L O G(F D)=C_{0}+C_{1} L O G(G P)+C_{2}(F R)+C_{3} L O G(B)
$$

In the above model LFD1 represent logarithm financial depth, FR2 financial repression of, LB3 logarithm per capita population per bank branch and is LGP4 logarithm of GDP per capita. In this model, due to variable dynamics of financial depth we use method econometric ARDL.

Introduce Variables: Indicators of financial depth: due to Iran conditions banks have formed the largest financial market; we must consider the indication that banks play a major role. So we could use of ratio Bank deposits and checking accounts to GDP. per capita banks: of indicators that could affect on the financial depth, is per capita individuals per bank, that for obtain it, we divide the number of individuals the community in each year on the number of banks in same year and we expect due to Iran's high inflation, whatever increase per capita customer per bank, being to rise in country's financial depth - GDP per capita: we use this model of non-oil GDP per capita to fixed price, because oil prices is constantly changing and has no effect on real income that reaches to individuals in the community .

Indicators of financial repression : real interest rates in Europe Union largely is represents global real interest rates, and among European countries the most powerful financial markets and banking system is 
related to the British that is determining the most in interest rates. To show the index of financial repression in Iran we consider difference real interest rates Britain and Iran. Namely whatever be more difference real interest rates in the two countries, represents that financial markets in Iran, more is suppressed by government and vice versa.

\section{Results}

Estimate model: Model desired estimate by software Microfit 4.1. By entering data related to Iran since 1976 until 2006, we consider interrupt 2, because our statistics is related to 31 years - Software Microfit using criteria $1 \mathrm{SBC}$, the optimal interrupt defines as ARDL $(2,0,0$, and 0$)$. Table related to variables and their coefficients is shown in Table (1-4).

Table 1: The results of short-term coefficients $(2,0,0,0)$ ARDL

\begin{tabular}{lllll}
\hline Variable & Coefficient & Standard error & t-statistic & Prob t \\
\hline LFD $(-1)$ & 1.1420 & 0.1809 & 6.3110 & 0.000 \\
LFD $(-2)$ & -0.7363 & 0.2394 & -3.0754 & 0.006 \\
FR & -0.0043 & 0.0015 & -2.8362 & 0.010 \\
LB & 0.9320 & 0.4116 & 2.2642 & 0.034 \\
LGP & 0.0598 & 0.0288 & 2.0783 & 0.050 \\
C & -7.9098 & 3.456 & -2.2885 & 0.032 \\
D & -0.0241 & 0.01103 & -2.1895 & 0.039 \\
\hline
\end{tabular}

Source: Attachments Computer (computing research)

In table (1) D, LGP, LB, LFD and FR are respectively represents financial, repression logarithm financial depth, logarithm per capita banks, logarithm per capita GDP without oil to fixed price and Dummy variable the war. $\mathrm{C}$ is the width of source Model .

The desired Model is as follows :

LFD=-7.9098+1.1420 LFD (-1)-0.7363 LFD (-2)-0.0043FR+0.9320 LB+0.0598 LGP-0.0241D

As can be seen due to results of Table (1), all variables used in Model are statistically meaningful in a high level and also signs of the coefficients are consistent with economic theory .

Test despite the long-run relationship: Coefficient of ECM (-1) obtained for the model presented in the table attached to the (0.594-) with probability $98 \%$ null hypothesis has been rejected based on lack of longterm relationship, and be clear that there is a long term relationship in the model if arise imbalance in the model, 59\% Imbalance be adjusted in the early years .

Structural stability test : Diagnostic tests, be used to determine stable model and determine the structural stability. For this purpose used the cumulative square, and total cumulative square residuals (CUSUM and CUSUMQ). For this purpose the two bands above and below is shown the significance level of $5 \%$, if statistical graphs obtained was located Ranged two band and is not discontinued them, $95 \%$ confidence level can be argued that the model it is very stable

\section{Estimated long-run model :}

Plot of Cumulative Sum of Recursive Residuals

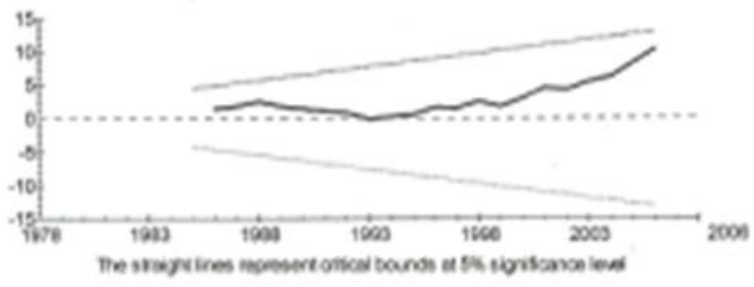

Plot of Cumulative Sum of Squares of Recursive Residuals

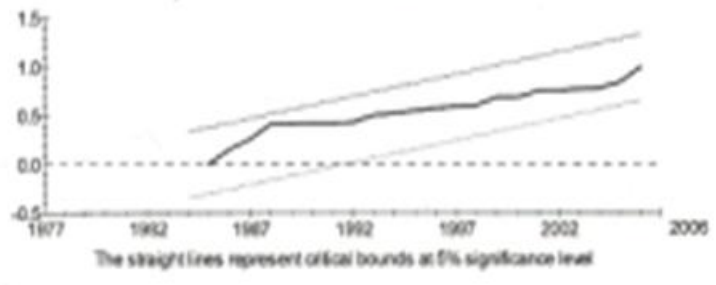

182 
Table 2: Results long-run coefficients ARDL $(2,0,0,0)$

\begin{tabular}{lllll}
\hline Variables & Coefficient & Standard error & t-statistic & Prob t \\
\hline FR & -0.0073 & 0.003317 & -2.2080 & 0.038 \\
LB & 1.5683 & 0.3365 & 4.6598 & 0.000 \\
LGP & 0.1007 & 0.0267 & 3.7638 & 0.001 \\
C & -13.308 & 2.700 & -4.9291 & 0.000 \\
D & -0.0406 & 0.017 & -3.4612 & 0.002 \\
\hline
\end{tabular}

Table Top D, LGP, LB, FR, are respectively represents financial repression, logarithm of per capita bank, logarithm of per capita GDP without oil fixed price and Dummy variables war. Also C is width of the source model.

Analysis results long-run estimates : Our long-run model is as follows :

$\mathrm{LFD}=\mathrm{C}+\mathrm{b}_{0} \mathrm{FR}+\mathrm{b}_{1} \mathrm{LB}+\mathrm{b}_{2} \mathrm{LGP}+\mathrm{b}_{3} \mathrm{D}$

With long-term coefficients obtained becomes as follows :

$\mathrm{LFD}=-13.308-0.0073 \mathrm{FR}+1.5683 \mathrm{LB}+0.1007 \mathrm{LGP}-0.0406 \mathrm{D}$

The results suggest that in the long run there is a negative relationship between financial repression and financial depth. Also customer per banks and GDP per capita has positive impact and significant on depth of financial in the long term

\section{Conclusion}

In this study at the beginning we introduce financial depth and financial repression, continued with glimpse of on financial repression in the Iran. We found that Iran is a country-based bank and has a weak capital markets - Iranian government in certain areas is running in financial repression and in the certain sectors has been weak. According to evidence it is clear that government obtain revenue through the financial repression, that suitable alternative is for received tax by government. Reason select model ARDL, is the dynamics that depth of financial explains as dependent variable model with non-stop .

Introduction model variables studied, between them is considered the best indicators for Iran and model estimates the software Microfit and it became clear that variables are significant in the short term and longrun and imposed war has remained, negative impact and significant on financial depth. On the basis of literature and model estimation in the paper, we can draw the following conclusions:

- Iran's government for two reasons does financial repression first, it is difficult direct tax collection in the Iran, and costly for government, that of the reasons, is there is no specific law and the inability government in the collecting taxes. Second, government cannot easily abandon financial repression, because Iran financial markets has not benefited of enough power and if full liberalization financial most likely irreversible impacts will be imported to country economy and banks .

- Financial depth in the short term is effective of financial depth to two periods before on that impact one period before on that positive and influence financial depth two periods before on that is negative and the sign is the dynamics of in the model .

- Financial Repression in the long-run has negative impact on financial depth - In appearance it may seem small its effectiveness coefficient, but as regards financial depth is fraction number and also logarithm has taken of the factor is not really small. Research hypothesis was represents the "Reducing in size of financial repression is cause improvement in financial depth in the country".

- Time finds intensity of financial repression on the markets are very weak, but financial markets in Iran are being privatized from mid 1370 onwards and yet have not global competitive strength, the compactness government with the intensity suppress them. The control too government and central banks, has been down the performance of banks and seems by reduction of financial repression, partly increase financial depth of in banking system . 
- According to estimated model is specified, per person per bank for a short stretch of deep financial is equal to 0.93. Namely increasing one per capita for each bank financial depth increases 0.93 percent. In the long run also is tension equal to 1.56 that is represents that by increasing one per capita population for each bank, financial depth will increase $1.56 \%$.

- GDP per capita has had positive impact on financial depth and in the short tension the depth of the financial 0.05 and indicates that by increasing one per capita gross domestic product, financial depth will increase $0.1 \%$.

- The imposed war has had the negative impact on the Iranian economy, estimation model also this issue confirms and the negative impact of war in short term and long-term is determined on financial depth.

- According to literature research, all developing countries have started that successful release, and releasing has been gently and uniformly. In Iran is necessary as a developing country liberalization of its markets occurs slowly and with uniformity. So mild reduction and uniform in financial repression is cause improvement monetary and financial markets .

\section{References}

Acarya, S. (2002). India: Crisis, Reforms and Growth in the Nineties, in: Working Paper Stanford University, No. 139, 1-40.

Ahluwalia, M., S. (2002). Economic reforms in India since 1991: Has Gradualism worked in? Journal of Economic Perspectives, 16(3), 67-88.

Brownbridge, M. \& Gayi, S. (1999). Progress constraints and limitations of financial sector reforms in the least developed countries. Finance and Development Research Program, Working Paper Series No. 7, Institute for Development Policy and Management, University of Manchester.

Fry, M. J. (1995). Money, Interest and Banking in Economic Development, London: John Hopkins University Press.

McKinnon, R. I. (1988a). Financial Liberalization in Retrospect: Interest Rate Policies in LDCs. in G. Ranis and T.P. Schultz (eds.), the State of Development Economics, Oxford: Basil Blackwell.

Pagano, M. (1993). Financial markets and growth: an overview: European Economic Review. 37, 613-622.

Samadi, A. H. (1999). Financial Deepening and Economic Growth in Iran in the presence of structural breaks. The Journal of Planning and Budgeting, 16, 58-59.

Shakeri, A. \& Khosravi, H. (2004). Theory test McKinnon- Shaw Iran's economy. Iranian Journal of Economic Research, No 14.

Shaw, E. S. (1973). Financial Deepening in Economic Development. New York: Oxford University press.

Tornell, A., Westermann, F. \& Martinez, L. (2004). The positive link between financial liberalization growth and crises; NBER Working Paper 10293. 